PRINT ISSN 1119-8362

Electronic ISSN 1119-8362
Full-text Available Online at

https://www.ajol.info/index.php/jasem

http://ww.bioline.org.br/ja
J. Appl. Sci. Environ. Manage.

Vol. 24 (11) 1899-1908 November 2020

\title{
Proximate and Mineral Elements Composition of Three Forest Fruits Sold in Port Harcourt, Nigeria
}

\author{
${ }^{1}$ OLADELE, AT; ${ }^{1}$ OFODILE, EAU; ${ }^{2}$ UDI, BT ; ${ }^{* 3}$ ALADE, GO \\ ${ }^{1}$ Department of Forestry and Wildlife Management, ${ }^{2}$ Institute of Agriculture, Research and Development, University of Port Harcourt, \\ Nigeria \\ ${ }^{* 3}$ Department of Pharmacognosy and Herbal Medicine, Niger Delta University, Wilberforce Island, Nigeria
}

"Corresponding Author Email: aladegideon@yahoo.com; Tel: +2348067368038

\begin{abstract}
This study aimed to assess the nutritional and trace elements composition of selected forest fruits sold for human consumption in Port Harcourt. Fruit contamination by heavy metals is an issue of global concern. Nondegradable elements bioaccumulations in tissues and organs have deleterious effects in man. Three (3) Agroforestry fruits species; (Spondias cytherea L. (Anacardiaceae), Syzygium malaccense (L.) Merr. \& L. M. Perry Myrtaceae and Cola pachycarpa K. Schum. Malvaceae) were purposefully selected and sourced from three strategically located markets namely; Oil mill, Choba and D/line fruit markets. The fruit species were procured and washed with distilled water and the edible parts extracted, chopped and sun dried properly. The nutritional composition was analyzed using $18^{\text {th }}$ edition of the Association of Official Analytical Chemist while trace metals were analysed using PIXE Accelerator. Spondias cytherea yielded high percentage of crude Protein $(8.373 \pm 0.1)$ and Fibre content $(11.73 \pm 0.03)$, while Syzygium malaccense was rich in Fat (7.17 \pm 0.02$)$ and Ash (4.17 \pm 0.04$)$. Moisture content was highest in Cola parchycarpa (12.63 \pm 0.05$)$. PIXE Accelerator analysis revealed that the fruits contain high concentration of trace metals; $S$. malaccense contained $\mathrm{Mg}$ $(1170 \pm 237.0 \mathrm{ppm}), \mathrm{Si}(60.02 \pm 68.95 \mathrm{ppm}), \mathrm{Al}(14.89 \pm 7.71 \mathrm{ppm}), \mathrm{Fe}(10.60 \pm 4.11 \mathrm{ppm}), \mathrm{Rb}(3.20 \pm 0.00 \mathrm{ppm})$ and $\mathrm{Ti}$ $(1.82 \pm 0.00 \mathrm{ppm})$. C. parchycarpa had Zn $(6.22 \pm 11.80 \mathrm{ppm}), \mathrm{Cr}(1.60 \pm 0.75 \mathrm{ppm}), \mathrm{Mn}(0.71 \pm 0.87 \mathrm{ppm})$ and $\mathrm{Cu}$ $(0.38 \pm 0.33 \mathrm{ppm})$. Ni $(0.16 \mathrm{ppm})$ was found only in $S$. cytherea fruit. The forest fruits are rich in nutrients vital for healthy growth but the level of heavy metals $(\mathrm{Mg}, \mathrm{Al}$. $\mathrm{Cr}, \mathrm{Fe}$ and $\mathrm{Zn}$ ) in each of the fruits were above WHO/FAO permissible limit, therefore excessive consumption on a daily/weekly routine should be avoided.
\end{abstract}

\section{DOI: https://dx.doi.org/10.4314/jasem.v24i11.9}

Copyright: Copyright $(C 2020$ Oladele et al. This is an open access article distributed under the Creative Commons Attribution License (CCL), which permits unrestricted use, distribution, and reproduction in any medium, provided the original work is properly cited.

Dates: Received: 20 September 2020; Revised: 29 October 2020; Accepted: 10 November 2020

Keywords: Forest fruits, proximate, heavy metals, human health

Safe and healthy foods are essential for survival, growth and productivity of all living organisms (Omoyajowo et al., 2017). Safe and nutritious foods contribute to healthy population of human societies globally. Food contamination by heavy metals and subsequent bioaccumulation of non-degradable element in living organisms especially human beings have deleterious effects. Several ailments in man have been associated with high concentration of heavy metals in the body (Jaishankar et al., 2014) and this is an issue of global concern. High level of heavy metals in human body can damage the functioning of the brain, lungs, kidney, liver, blood composition and other important organs. Long-term exposure can lead to Parkinson's and Alzheimer's diseases, muscular dystrophy and cancer amongst others (Jarup, 2003). Fruits are important component of human diet, they are good sources of vitamins and mineral salts (Maha and Ahmed, 2015). Most rural populations in Africa depend on wild fruits and vegetables from the forests for intake of vitamins and micronutrients especially during the off-farm seasons (Dry season). Wide range of edible fruits in the wild includes nuts and seeds used as food supplement (Tehoundjan et al., 2002, Nwiisuator et al., 2012). These forest fruits have played significant roles in rural population food security for centuries till now. Blaney et al. (2009) reported dietary nutrient adequacy in children over 2 years to young adults have been associated with wild fruits and animals in Gabon. In southern Nigeria, fruits such as Dacryodes edulis, Chrysophyllum albidum, Pluckenetia conoflora, Blighia sapida and Irvingia gabonensis provide off season food because they often mature when cultivated staples such as rice, yam, cocoyam are yet to mature (Aju, 2014). Proximate analysis of edible fruits plays a crucial role in assessing their nutritional significance (Pandey et al., 2006). Understanding the nutritional content of a food item is critical in the determination of its relevance to human health and food security while determination of heavy metals provide to a good extent the safety of such food. Heavy metals are generally referred to as 
those metals which possess a specific density of more than $5 \mathrm{~g} / \mathrm{cm}^{3}$ and adversely affect the environment and living organisms (Jarup, 2003).

The potential accumulation in different organs of the body thus leads to disastrous side effects (Lenntech, 2004; Ming-Ho, 2005; Aderinola et al., 2009). Technology advancement has instigated the integrity of the environment with emission or discharge of effluents containing these heavy metals (Fulekar et al., 2009; Sabiha-Javied et al., 2009). Furthermore, high consumption of heavy metal contaminated food can seriously deplete some essential nutrients in the body thereby causing decrease in immunological defenses, impaired psycho-social behavior and disabilities associated with malnutrition (Ogbuagu et al., 2015).

Particularly bio accumulation of Cadmium could result to ovarian Cancer and renal prostrate (WHO, 1992; Satarug et al., 2010) while high concentration of lead $(\mathrm{Pb})$ results in cardiovascular diseases, decreases sperm count and spontaneous abortions (WHO, 1992; Hertz-Piccitto, 2000). Polluted environment serve as sources of heavy metals in fruits and vegetables which could hinder their growth and productivity and can also lead to poor vegetation growth and lower plant resistance against pests (Ene et. al., 2009).

In general, heavy metal contaminants in and other sources could threaten fruits quality meant for human population. It is advocated that flooding from heavy downpour may lead to horizontal leaching from dump sites causing metal uptake by roots of crops while the rest may find their way into open water bodies and the entire ecosystem, the entry into food chain of these metals leads to increased susceptibility and exposure to metal poisoning of local population (Zukowska and Biziuk, 2008). Port Harcourt is the heartbeat of oil rich Niger Delta region, but the region experienced flood annually since year 2012 .

This is one of the channels by which heavy metals are being transported, accumulated in the soil and subsequently enters human body system via plant foods.

The urgency of the world food problems has thrown challenges to farmers and nutritionists alike to investigate the possibility of utilizing some plants species as additional sources of nutrients (Nwiisuator et al., 2012). Also the safety of fruits consumed by humans and organisms is very essential to life. This research is therefore aimed at analyzing the proximate and mineral elements composition of three fruits of economic importance sold and consumed by people in Port Harcourt, Rivers state, Nigeria.

\section{MATERIALS AND METHODS}

Study Area:Port Harcourt city has estimated mean altitude $12 \mathrm{~m}$ above sea level, located in the eastern part of the Niger Delta and a predominantly low-lying alluvial state in southern Nigeria. It is characterized by heavy and lengthy raining season (February November) while December and January make up the dry season with a mean maximum and minimum temperature of approximately $31.6^{\circ} \mathrm{C}$ and $23.2^{\circ} \mathrm{C}$, respectively (NBS, 2011). The months of April through October have the highest temperatures (Okhumode, 2018). The vegetation zones consist of two zones; mangrove swamps and freshwater swamp forests. Rivers state occupies $10,575 \mathrm{~km}^{2}$ with a projected population of 7,303,924 as at 2016 (NBS, 2018).

Description sample materials: The selected fruits include Spondias cytherea L. (Anacardiaceae) commonly known as Plum, it is an exotic fruit and originated in the south Pacific (Mohammed et al., 2017) and now broadly cultivated in the moist rain forest of coastal area in Nigeria. It is also cultivated as ornamental tree within Port Harcourt metropolis. Syzygium malaccense (L.) Merr. \& L.M. Perry (Myrtaceae), commonly known as Local apple; is an exotic species that have been cultivated for a long time. Its native range lies in Indo-malaya, south-east Asia and Melanesia (Whistler and Craig, 2006) and Cola pachycarpa K. Schum. (Malvaceae) commonly known as Monkey kola and locally called Ochiricha or Achicha in Igbo language. It is a tropical species found in lowland forest of some West African countries including Cameroun, Gabon and Nigeria (Keay et al., 1964).

Sample Collection: Matured ripe fruits of Spondias cytherea (Plum), Syzygium malaccense (Local apple) and Cola parchycarpa (Monkey kola) were selected due to their abundance and consumption across all social classes. Three (3) major fruits markets across Port Harcourt metropolis were selected to source the fruits namely; Choba market (Long. $4^{\circ} 53^{\prime} 18 \mathrm{~N}$ Lat. $6^{\circ} 54^{\prime} 2 \mathrm{E}$ ), Oil mill market Long. $4^{\circ} 51^{\prime} 33 \mathrm{~N}$ Lat. $7^{\circ}$ $3^{\prime} 50^{\prime} \mathrm{E}$ and D-line fruit market (Long. $4^{\circ} 47^{\prime} 58 \mathrm{~N}$ Lat. $7^{\circ} 0^{\prime} 2 \mathrm{E}$ ). The selected fruit markets are evenly distributed to cover the entire Port Harcourt metropolis, which would enable evenly distributed and unbiased result.

Sample Processing: The fruits samples were washed thoroughly with distilled water to remove the dust, soil and other forms of impurities. The pericarp of $S$. cytherea was peeled to obtain the edible mesocarp while $S$. malaccense and peeled $C$. parchycarpa were cut into two parts in order to remove the seed. The 
fruits were opened longitudinally with a sharp knife to extract the edible mesocarp (Plate 1). Samples of each fruit sourced from the three markets were chopped separately with knife into a nearly uniform size in other to facilitate drying and grounding processes. They were thereafter sun dried until they were brittle and crispy.

The dried samples were grounded in agate mortar and mixed with $10 \%$ by weight of ultra-pure graphite powder and prepared into thick pellets of $13 \mathrm{~mm}$ diameter without binder. They were then packaged in transparent polythene bags and properly labeled.

Proximate analysis: Proximate analysis of the fruits was carried out following A.O.A.C., (2005) methods and standards at the Institute of Agriculture Research and Training (IART), Ibadan, Nigeria. All analyses were carried out in triplicates.

Analyses of metal contents: Trace elements were analyzed at the Centre for Energy Research and Development (CERD), Obafemi Awolowo University (OAU), Ile-Ife. PIXE analysis was done using NEC 5SDH 1.7MV Pelletron Accelerator, equipped with a radiofrequency charge exchange ion source, which is equipped to provide proton and helium ions. Using 2.5 $\mathrm{MeV}$ proton beam obtained from CERD ion beam analysis (IBA) facility.

The end-station of NEC 5SDH 1.7MV Pelletron Accelerator consists of an Aluminum chamber of about $150 \mathrm{~cm}$ diameter and $180 \mathrm{~cm}$ height. This has four ports and a window. Port 1 at $165^{\circ}$ is for the RBS detector, Port 2 at $135^{\circ}$ is for PIXE detector, port 3 at $30^{\circ}$ is for the ERDA detector, the window at $0^{\circ}$ is for PIGE. The chamber has a sample ladder that can carry 11 (eleven) $13 \mathrm{~mm}$ diameter sample. Port 2 at $135^{\circ}$ which is for PIXE detector was used in analysis of heavy metal composition of the samples.

The end station has a turbo pump and a variable beam collimator to regulate beam size, and an isolation value. Apple leaves were used as the certified standard for the quantitative analyses of the fruits. It was used for the determination of the $\mathrm{H}$-value of the samples. The measurements were carried out with a beam spot of $4 \mathrm{~mm}$ in diameter and a low beam current of 3-6nA .
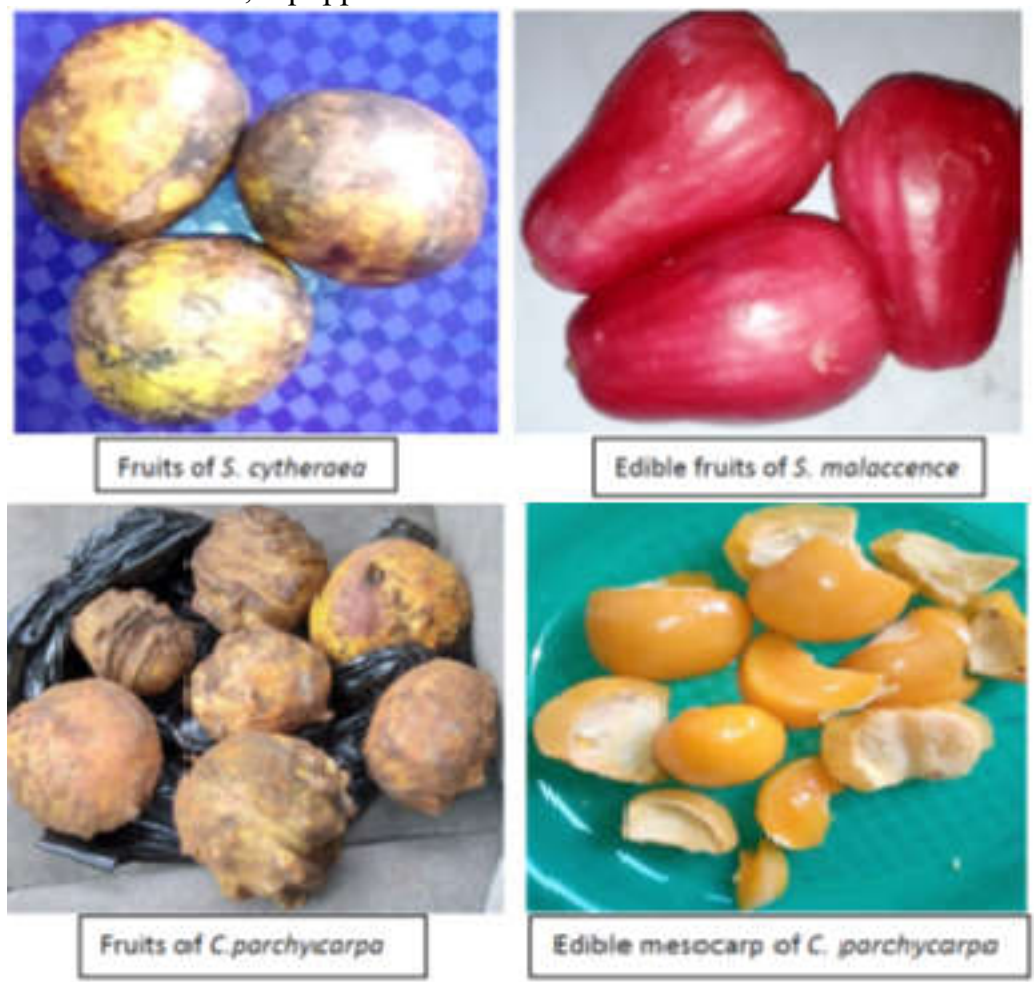

Plate 1: Fruits of Spondias cytherea (Plum), Syzygium malaccense (Local apple) and Cola parchycarpa (Monkey kola) sold in Port Harcourt 
The irradiation was for about 10-20 minutes. A Canberra $\mathrm{Si}(\mathrm{Li})$ detector Model ESLX 30-150, Berryllium thickness of $25 \mu \mathrm{m}$, with full width half maximum (FWHM) of $150 \mathrm{eV}$ at $5.9 \mathrm{keV}$, with the associated pulse processing electronics and a Canberra Genie 2000 (3.1) MCA card interfaces to a PC were used for the X-rays data acquisition. With respect to the beam director, the sample's normal was located at $0^{\circ}$ and the $\mathrm{Si}(\mathrm{Li})$ detector at $45^{\circ}$. The PIXE set-up was calibrated using some pure element standards and NIST geological standard, NBS278.

The computer code GUPIXWIN (Maha, and Ahmed, 2015) was uses for the analysis of the PIXE data. This provide a non-linear least square fitting of the spectrum, together with subsequent conversion of the fitted X-ray peak intensifies into elemental concentrations, utilizing fundamental parameter methods for quantitative analysis.

\section{RESULTS AND DISCUSSION}

Fruits provides array of nutritional benefits and can significantly influence the quality of food intake by the population. Fruits are a good source of natural vitamins that helps in maintaining healthy body and also play a vital role in immunological defense. Proximate analysis of the forest fruits showed that the three fruits were rich in protein content; Spondias cytherea $(8.37 \pm 0.10 \mathrm{~g})$ was highest in crude protein (Table 1) while Syzygium malaccense had $5.43 \pm 0.06 \mathrm{~g}$ of protein. There are no significant differences in the protein concentration of the forest fruits. Crude proteins are essential component of diets needed for normal growth and cell building; it is a function of calculated Nitrogen minerals available in a particular food substance. Proteins supply the required amino acids essential for body building and maintenance of proper $\mathrm{pH}$ in nutrition (Pugalentnal et al., 2004; Hamm et al., 2015). Its deficiency could pose serious health challenges especially in developing countries where average family food intake is usually inadequate and mostly of poor quality (Ruel et al., 2013). Fruits are major sources of protein in human diet; however, in many circumstances they are not readily available or not affordable in many poor countries. Composition of crude protein in the fruits studied are higher than fruits of several other common fruits in the local markets such as Avocado pear Persea americana, Sweet orange-Citrus sinensis and Watermelon - Citrullus lanatus grown in Nigeria (Nnaji and Okereke, 2016; Omoyajowo, 2017). The result indicates $S$. cytherea, $C$. pachycarpa and $S$. malaccense were relatively rich in crude protein compared to some common fruits in the market. However, Christopher and Dosunmu, (2011) reported a slightly higher protein content in African star apple fruits Chrysophyllum albidium $(5.66 \pm 0.01)$ when compared to that of $S$. malaccense $(5.43 \pm 0.06)$. C. albidum is a seasonal forest tree species of great potential; juice and wine have been reportedly produced from its fruit sap (Jimoh et al., 2014; Kadiri et al., 2016), hence several forest fruits not presently considered as staple fruits in our diets are rich in protein content and can contribute to food security in sub Saharan West Africa.

Table 1: Proximate Composition (\%) of Three Forest fruits sold in Port Harcourt, Nigeria

\begin{tabular}{|c|c|c|c|c|}
\hline \multirow{2}{*}{ Nutrients $(\%)$} & \multicolumn{3}{|c|}{ Plant Species (Mean \pm SD) $n=3$} & \multirow{2}{*}{ LSD } \\
\hline & S. cytherea & C. parchycarpa & S. malaccense & \\
\hline Crude protein & $8.37 \pm 0.10^{\mathrm{a}}$ & $7.78 \pm 0.09^{\mathrm{b}}$ & $5.43 \pm 0.06^{\mathrm{c}}$ & 0.167 \\
\hline Crude fat & $2.28 \pm 0.03^{\mathrm{b}}$ & $2.08 \pm 0.04^{\mathrm{c}}$ & $7.17 \pm 0.02^{\mathrm{a}}$ & 0.063 \\
\hline Crude fibre & $11.73 \pm 0.03^{\mathrm{a}}$ & $3.46 \pm 0.02^{\mathrm{b}}$ & $1.94 \pm 0.02^{\mathrm{c}}$ & 0.063 \\
\hline Ash & $3.69 \pm 0.02^{\mathrm{b}}$ & $4.13 \pm 0.04^{\mathrm{a}}$ & $4.17 \pm 0.04^{\mathrm{a}}$ & 0.063 \\
\hline Moisture & $12.10 \pm 0.05^{\mathrm{b}}$ & $12.63 \pm 0.05^{\mathrm{a}}$ & $11.64 \pm 0.04^{\mathrm{c}}$ & 0.089 \\
\hline
\end{tabular}

Although fats formed a major source of energy in the body, Mgbemena et al., (2019) recommends a maximum daily intake of 30 calories for adult to avoid obesity, diabetes and heart diseases. The values of fats obtained in the three fruits showed that they contain high fat contents of $2.08-7.17$ percentage range. $S$. malaccense have the highest fat content (7.17\%). These fruits if consumed will render energy for proper body functioning especially among children and young adults. $S$. malaccense is commonly known as local apple and it's affordable by the poor people. The three tree species readily grows within the Niger Delta ecosystems and sometimes used as ornamental trees in homesteads. This attributes placed them at advantage over expensive fruits such as Apple and Avocado pear if cultivated on commercial scale. An average size apple fruit (Malus domestica) cost $100-150 \mathrm{~N}$ (Nigerian Naira) while the local apple (S. malaccense) of the same size cost $40-50 \mathrm{~N}$. Also the fat contents are higher than those reported for some common fruits such as Mango and Banana values of 0.4 and $0.6 \mathrm{~g} / 100 \mathrm{~g}$ respectively (Guiamba, 2016; Dotto et al., 2019).

Crude fibres contribute little to nutritional value of foods but help in proper peristaltic functioning of the alimentary system; it is made of cellulose, hemicellulose, pectic substances, gums, mucilages and 
a non-carbohydrate component lignin which traps water and supply roughage (Dhingra et al., 2012; Mgbemena et al., 2019). It impacts healthy living positively by assisting in disease prevention. $S$. cytherea fruit was very rich in crude fibre content (11.73\%) while S. malacense had the least value for crude fibre (1.94\%). Consumption of $S$. cytherea fruits can aid proper functioning of the digestive system. Other common fruits sold in the market such as Banana (5.10\%), Pineapple (10.20\%), Hog plum (Spondias mombin - 4.2\%) and Carica papaya $(11.06 \%)$ have lower fibre levels as observed by other workers (Bala and Bashar, 2017). Constipation and colon cancer caused by indigestion can be prevented at a cheap cost with consumption of these forest fruits. High moisture content promotes fruit spoilage by microorganism in storage but it also determines freshness of the fruit. The moisture content values of the fruits fall within the stipulated range (8-14\%) for vegetable drugs, which shows that they can be stored for a while without spoilage (Abere and Onwukaeme, 2012). Moisture content values of the three fruits investigated were lower than the findings of Christopher and Dosunmu (2011) on C. albidium (66.67 \pm 0.02$)$, another common forest fruit in the area. The shelf lives of the fruits are relatively longer than common staple fruits such as Mango and Sweet orange that spoil within 5-7 days, $C$. pachycarpa can be in storage for about two weeks without spoilage and still remain firm provided the pods are intact (Koyejo and Okonkwo, 2013). Total ash measures the extent of foreign inorganic impurity and contamination with sand, earth, that is, the level of measures employed in drug preparation and which should not exceed $15 \%$ (Bigoniya et al., 2012). Ash contents of the selected fruits of study were all within the acceptable range $S$. cytherea (3.69 \pm 0.02$), C$. pachycarpa $(4.13 \pm 0.04)$ and $S$. malaccense $(4.17 \pm 0.04)$. Consumption of the fruits does not predispose consumers to accumulation of impurities in the body; hence the proximate results showed that the fruits have the capacity to improve human health. Statistical test on the mean compositions showed significant differences in the composition of crude protein, fat, fibre and moisture content of the three fruits. While the ash composition of $C$. parchycarpa and S. malaccense revealed no significant differences in their means.

Trace element content in the Edible parts of selected forest fruits in Port Harcourt: Comparative concentration of trace elements in the three forest fruits procured from Choba, Oil mill and D/line Fruit markets in Port Harcourt showed no significant differences in the mean concentrations of all the mineral elements found in the selected fruits species (Table 2). Eleven elements were detected in the three different fruits samples viz: $\mathrm{Mg}, \mathrm{Al}, \mathrm{Si}, \mathrm{Cr}, \mathrm{Fe}, \mathrm{Zn}, \mathrm{Ti}$, $\mathrm{Rb}, \mathrm{Mn}, \mathrm{Cu}$ and $\mathrm{Ni}$. Lead $(\mathrm{Pb})$ was not detected in any of the three fruits. Some of these elements are vital to physiological and normal metabolic activities required for proper body growth and good health, however, higher concentrations above permissible levels could lead to several human disease conditions. Magnesium $(\mathrm{Mg})$ was observed to be the highest in S. malaccense $(1170.0 \pm 237.00 \mathrm{ppm})$ and least in $S$. cytherea $(960.87 \pm 126.43 \mathrm{ppm})$. Magnesium is a cofactor in more than 300 enzymes systems performing critical role in energy production and nucleic acid synthesis (Schwalfenberg and Genuis, 2017). $\mathrm{Mg}$ is also useful in preventing some heart disorders, high blood pressure and improved lung function if within regulated limits (Olabanji et al., 2014). Its deficiency (hypomagnesaemia) can lead to neuromuscular, cardiac or nervous disorders (Jahnen-Dechent and Ketteler, 2012), while excessive intake of magnesium can result in hypotension and other cardiovascular effects as well as neuromuscular manifestations (Swaminathan, 2003). Magnesium provisional recommended daily allowance (RDA) for adult is 400 - 420mg and 130 - 240mg for children aged $9-$ 13years (NAP, 1997). Many authors (Heaton, 2003; King et al., 2005; Griffiths et al., 2012) have reported insufficient magnesium intake across populations globally with staple foods such as meat, sugar and white flour contributing less than $20 \%$ of RDA. However, the three forest fruits species under study recorded high Magnesium content above RDA limits. The fruits are seasonal in supply, hence their availability in the market is also seasonal therefore they are not consumed as a routine diet; attaining above maximum magnesium intake limit is practically difficult. Usually, the fruits are not consumed in large quantities of up to $1 \mathrm{~kg}$ daily. Some of these lesser utilized local forest fruits served as snacks and contribute to rural house hold food security and income over time without documented record of hypermagnesaemia within the rural population. They have been complementing magnesium sources in the body but not properly documented for long. $S$. malaccense had highest concentration of Aluminum (244.60 $\pm 126.39 \mathrm{ppm})$ while $S$. cytherea and $C$. parchycarpa were $166.40 \pm 63.57 \mathrm{ppm}$ and $166.40 \pm 63.57 \mathrm{ppm}$, respectively. Aluminum is a nonessential element and its accumulation can cause series of ailments in humans such as central nervous, skeletal, Alzheimer's diseases and hematopoietic systems of humans (Domingo, 1995) especially in patients with renal dysfunction (Ekanem et al., 2009). Compositions of $\mathrm{Al}$ in the three fruits were higher than the recommended provisional weekly intake of $60 \mathrm{mg} /$ week for adult (FAO/WHO, 2011), hence their consumptions in large amount are not highly 
recommended as a routine diet. However, Njenga et al., (2007) opined that most Aluminium consumed does not accumulate in the body to the point of toxicity since some ligands such as fluoride and citrate are required for Aluminium to be absorbed by the intestine; they are usually excreted from the body. Even though there is the need to exercise precautions in ingesting excess $S$. malaccense particularly, possibility of Aluminium toxicity is very low. In similar findings high levels $(321.78 \mathrm{mg})$ of $\mathrm{Al}$ has been reported in fresh vegetable juices and grains consumed daily for therapy in Kenya and China without associated toxicity or safety concerns (Njenga et al., 2007; Liang et al., 2019).

Table 2: Mean Concentrations (ppm) of Trace elements in edible parts of $S$. cytherea, C. parchycarpa and $S$. malaccense obtained in Port Harcourt

\begin{tabular}{|c|c|c|c|c|c|c|c|}
\hline \multirow[b]{3}{*}{$\begin{array}{l}\text { Heavy } \\
\text { metals }\end{array}$} & \multicolumn{6}{|c|}{ Plant Species (Mean \pm SD) } & \multirow[b]{3}{*}{ LSD } \\
\hline & \multicolumn{2}{|c|}{ S. cytherea } & \multicolumn{2}{|c|}{ C. pachycarpa } & \multicolumn{2}{|c|}{ S. malaccense } & \\
\hline & $\begin{array}{l}\text { Trace elements } \\
\text { concentration } \\
\text { (ppm) }\end{array}$ & $\begin{array}{l}\text { EADC } \\
\text { (ppm) }\end{array}$ & $\begin{array}{l}\text { Trace elements } \\
\text { concentration } \\
(\mathrm{ppm})\end{array}$ & $\begin{array}{l}\text { EADC } \\
\text { (ppm) }\end{array}$ & $\begin{array}{l}\text { Trace elements } \\
\text { concentration } \\
(\mathrm{ppm})\end{array}$ & $\begin{array}{l}\text { EADC } \\
\text { (ppm) }\end{array}$ & \\
\hline $\mathrm{Mg}$ & $960.87 \pm 126.43$ & 124.8 & $1063.77 \pm 352.45$ & 112.85 & $1170.0 \pm 237.00$ & 142.44 & NS \\
\hline $\mathrm{Al}$ & $166.40 \pm 93.93$ & 21.63 & $166.40 \pm 63.57$ & 17.65 & $244.60 \pm 126.39$ & 29.77 & NS \\
\hline $\mathrm{Si}$ & $354.87 \pm 232.46$ & 46.13 & $426.33 \pm 291.03$ & 45.23 & $986.13 \pm 1130.76$ & 120.03 & NS \\
\hline $\mathrm{Cr}$ & $14.83 \pm 31.56$ & 1.93 & $30.25 \pm 14.21$ & 3.21 & $25.00 \pm 10.87$ & 3.04 & NS \\
\hline $\mathrm{Fe}$ & $114.43 \pm 43.34$ & 14.87 & $118.80 \pm 64.46$ & 12.60 & $174.20 \pm 67.44$ & 21.20 & NS \\
\hline $\mathrm{Zn}$ & $58.77 \pm 54.18$ & 7.64 & $117.30 \pm 187.68$ & 12.44 & $42.90 \pm 54.99$ & 5.22 & NS \\
\hline $\mathrm{Ti}$ & $21.20 \pm 2.55$ & 2.76 & $21.75 \pm 6.01$ & 2.31 & $29.90 \pm 0.00$ & 3.64 & NS \\
\hline $\mathrm{Rb}$ & $43.30 \pm 0.00$ & 5.63 & $45.30 \pm 0.00$ & 4.81 & $52.50 \pm 0.00$ & 6.39 & NS \\
\hline Mn & $9.20 \pm 2.40$ & 1.20 & $13.45 \pm 13.79$ & 1.43 & - & & - \\
\hline $\mathrm{Cu}$ & $3.10 \pm 0.85$ & 0.40 & $7.15 \pm 5.30$ & 0.76 & - & & - \\
\hline $\mathrm{Ni}$ & 2.5 & 0.33 & - & & - & & - \\
\hline A.W.E.P & $65.02 \pm 0.01$ & & $53.04 \pm 0.04$ & & $60.86 \pm 0.08$ & & \\
\hline
\end{tabular}

C. parchycarpa had the highest mean concentration of Chromium (Cr) with $30.25 \pm 14.21$, S. malaccense

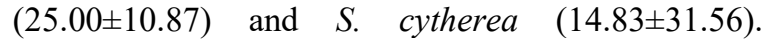
According to Oladele and Fadare (2015), Chromium (III) is an essential element for healthy growth while Chromium (VI) compounds are toxics and carcinogenic in humans. The problems that are associated with chromium involve skin rashes, stomach ulcer, kidney, liver damages, lungs cancer and ultimate death (Oladele and Fadare, 2015; Muhammad and Sreebas, 2012). The permissible limit set by FAO/WHO (1984) for daily intake in edible plants was $0.02 \mathrm{ppm}$ for adult. Therefore, the fruits are not encouraged to be choice fruits on daily basis except taken as occasional snacks. Iron is essential for various body metabolic activities; especially as components of haemoglobin and oxygen transport in the body system. Its' deficiency leads to anaemia which is usually associated with fatigue, heart failure/palpitations, pale skin, and breath seizure. Iron is required for physical development and growth, as well as production of certain hormones (Aggett, 2012). Abbaspou et al., (2014) noted that unregulated Iron leads to tissue damage. Concentrations of Iron $(\mathrm{Fe})$ were $174.20 \pm 67.44,118.80 \pm 64.46$ and $114.43 \pm 43.34$ in $S$. malaccense, $C$. parchycarpa and $S$. cytherea respectively. The levels of $\mathrm{Fe}$ detected in the forest fruits were far above the recommended daily allowance (RDA) of $11-18 \mathrm{mg}$ for $14-51$ years' individuals, while estimated average tolerable upper limits Iron intake is $45 \mathrm{mg}$ daily $(\mathrm{NIH}, 2020$; WHO
(2008) observed that approximately 1.62 billion people globally are anaemic and half of the figure associated with iron deficiency. Iron deficiency was noted to be a risk factor affecting about 2 billion people globally (Zimmermann, 2007). In Nigeria, Oluwole and Agboola (2018) estimated Iron deficiency anaemia (IDA) among children below age five $(<5)$ at $22.3 \%$ and $75.6 \%$ among pregnant women in Northern Nigeria alone. It is noteworthy that the cheapest sources of nutritional iron in developing countries such as Nigeria are mainly local fruits and vegetables. Fruits are good sources of Iron, however, regulated quantities of the studied fruits are recommended to prevent tissue damage due to accumulated levels of Iron in the human body. However, the three fruits are really not consumed daily in the study area; they are occasional snacks when the fruits are in their productive seasons, hence they are unlikely to cause health risks. However, human bodies regulate excess iron levels by excreting via urine, stool, skin and during monthly menstrual cycle in women (McDowell, 2003).

Manganese (Mn) is vital for growth and health maintenance; it is related to antioxidant systems, carbohydrate and fat metabolism (Muhammad and Sreebas, 2012; Avila et al., 2013). Excessive intake has been noted to cause neurodegenerative disorder while Mn deficiency is rare in man but could result in poor skeletal development and low fertility (Finley et al., 2003) if it occurs. C. parchycarpa (13.45 \pm 13.79$)$ 
and $S$. cytherea $(9.20 \pm 2.40)$ fruits had high levels of Manganese (Mn) while it was not detected in $S$. malaccense fruit samples used in this study.

IOM, (2001) gave the recommended daily allowance (RDA) of $\mathrm{Mn}$ as $2.3 \mathrm{mg} / \mathrm{kg}$ while $\mathrm{FAO} / \mathrm{WHO}$ (1984) recommended provisional daily tolerable intake of $2.5 \mathrm{mg} / \mathrm{kg}$ for adult (19-51years). However, concentrations of $\mathrm{Mn}$ in the fruits were above the permissible limits. Crude oil polluted soil of $<5 \mathrm{pH}$ ignites accumulation of soluble Aluminum and Manganese compounds (Osuji and Ezebuiro, 2006).

Such accumulation creates good condition for $\mathrm{Mn}$ uptake by plants which could be traced to high levels of these compounds in the fruits. Local farmers and fruit collectors' source fruits from wild sources of which the soil may have been polluted and in turn sell to unsuspecting consumers.

There are high possibilities that the fruits are sourced from around or within Rivers state which is classified core crude oil exploration area in Nigeria. Zinc $(\mathrm{Zn})$ and Copper $(\mathrm{Cu})$ concentration were also high in the fruits. Zinc is essential for variety of enzymes in man; toxic doses have been implicated for slow growth and delayed sexual organs maturation (Alysson and Fabio, 2014).

$\mathrm{Cu}$ acts as metalloproteins and enzymes in the body, deficiency could lead to kidney and liver dysfunction. Provisional maximum tolerable daily intakes (PMTDI) are $0.3-1$ and $0.05-0.5 \mathrm{mg} / \mathrm{kg}$ body weight for $\mathrm{Zn}$ and $\mathrm{Cu}$ respectively (FAO/WHO, 2011). Though, high Zinc and $\mathrm{Cu}$ content of the three fruits make them unsuitable as routine diet considering the associated health risks, however they are rarely consumed in excess quantity above $1 \mathrm{~kg}$ daily.

The quantities of heavy metals that an individual could possibly consume daily were calculated; the edible parts of Ten (10) fruits each were extracted and weighed fresh as consumed. Average weight of consumable part per fruit showed Spondias cytherea $(65.02 \pm 0.01 \mathrm{~g})$, Cola parchycarpa $(53.04 \pm 0.04 \mathrm{~g})$ and Syzygium malaccense $(60.86 \pm 0.08 \mathrm{~g})$.

The recommended daily allowances of the elements were given in $\mathrm{mg} / \mathrm{kg}$; none of the edible parts in the fruits weighed up to a $\mathrm{kg}$. Hence consuming average of two fruits daily for all the three fruits were below RDAs indicating they are safe to consume (Table 2).
Conclusion: The three fruit species ( $S$. cytherea, $C$. parchycarpa and $S$. malaccense) were found to be rich in trace elements and can be considered safe for consumption provided they are limited to average of two fruits daily. The presence of trace elements in excessive high concentrations in these locally consumed common fruits may not be unconnected to the prevalence of crude oil exploration and exploitation in Rivers state. There is therefore, a need for formulation of enabling policies to secure safe consumption of fruits in this area.

Acknowledgement: The Authors acknowledge the support from Center for Energy Research and Development (CERD), Obafemi Awolowo University, Ile - Ife and Institute of Agriculture Research and Training (IAR\&T), Ibadan laboratories for the PIXE and Proximate analysis respectively.

\section{REFERENCES}

Abbaspour, N; Hurrell, R; Kelishadi, R (2014). Review on iron and its importance for human health. J Res Med Sci. 19:164-74

Abere, TA; Onwukaeme, DN (2012). Pharmacognostic Evaluation of the Leaves of Secamone afzelii (Schult) K Schum (Asclepiadaceae). Trop. J. Pharm Res. 11 (1):125131

Aderinola, OJ; Clarke, EO; Olarinmoye, OM; Kusemiju, V; Anatekhai, MA (2009). Heavy metals in Surface Water Sedimentation and Periwinkles of Lagos lagoon. Am. Eurasian J. Agric Environ Sci. 5(5): 609-617

Aggett, PJ (2012). Iron. In: Erdman J.W, Macdonald I.A, Zeisel S.H, eds. Present Knowledge in Nutrition. 10th ed. Washington, DC: WileyBlackwell, 506-20.

Aju, PC (2014). The role of forestry in agriculture and food security. Am J Res Commun. 2(6): 109-121.

Alysson, RBS; Fábio, C (2014). Risks of Heavy Metals Contamination of Soil-Plant system by land application of sewage sludge: A Review with Data from Brazil, http://dx.doi.org/10.5772/58384

Association of Official Analytical Chemist (2005). A.O.A.C, $18^{\text {th }}$ Edition.

Avila, DS; Puntel, RL; Aschner, M (2013). Manganese in health and disease. Met Ions life Sci. 13:199-227. 
Bala. M; Bashar, JB (2017). Analysis of nutritive contents of some Nigerian fruits. BAJOPAS. 10(2):204 - 208 .

Bigoniya, P; Singh, CS; Srivastava, B (2012). Pharmacognostical and physico-chemical standardization of Syzygium cumini and Azadirachta indica seed. Asian Pac. J. Trop. Biomed. S290-S295.

Blaney, S; Beaudry, M; Latham, M (2009). Contribution of natural resources to nutritional status in a protected area of Gabon. Food \& Nutr Bull. 30(1):49-62.

Christopher, EA; Dosunmu, MI (2011). Chemical evaluation, proximate composition, ascorbic acid and anti- nutrients content of African Star Apple (Chrysophyllum afracanum) fruit. IJRRAS. 9(1): 146 - 149 .

Dhingra, D; Michael, M; Rajput, H; Patil, RT (2012). Dietary fibre in foods: a review. J Food Sci. Tech. 49(3):255-266.

Domingo, JL (1995). Reproductive and developmental toxicity of Aluminium: a review, Neurotoxicol. Teratol. 17:515-521.

Dotto J, A. O. Matemu, P.A. Ndakidemi. 2019. Nutrient composition and selected physicochemical properties of fifteen Mchare cooking bananas: A study conducted in northern Tanzania. Scientific African 6, e00150, 1-9.

Ekanem, EJ; Lori, JA; Okibe, FG; Shallangwa, GA; Anhwange, BA; Haliru, M; Moyosore, AA (2009). Determination of Aluminium in different sources and its contribution to daily dietary intake in Nigeria. J. Appl. Sci. Res. 5(8): 944-948.

Ene, A; Bosneaga, A; Georgescu, L (2009). Determination of heavy metals in soil using XRF technique. Rom. J. Phys. 55(7-8): 815-820

FAO/WHO (1984). Toxicological evaluation of certain food additives and food contaminants. (Twenty-eight meeting of the Joint FAO/WHO Expert Committee on food additives). Washington, DC: ILSI Press International Life Sciences Institute

FAO/WHO. 2011. Evaluation of Certain Food Additives and Contaminants, Seventy-third report of the Joint FAO/WHO Expert Committee on
Food Additives, WHO Technical Report Series 960, Geneva. Pgs 237.

Finley, JW; Penland, JG; Pettit, RE; Davis, CD (2003). Dietary manganese intake and type of lipid do not affect clinical or neuropsychological measures in healthy young women. J. Nutr. 133(9):2849-56.

Fulekar, M; Singh, A; Bhaduri, AM (2009). Genetic engineering strategies for enhancing photoremediation of heavy metals. Afr. J. Biotechnol. $8: 529-535$

Griffiths AM; Cook, DM; Eggett, DL; Christensen, MJ (2012). A retail market study of organic and conventional potatoes (Solanum tuberosum): mineral content and nutritional implications. Int $J$ Food Sci Nutri. 63(4):393-401.

Guiamba, I (2016). Nutritional Value and Quality of Processed Mango Fruits. Thesis for the Degree of Doctor of Philosophy, Food and Nutrition Science, Department of Biology and Biological Engineering, Chalmers University of Technology, Göteborg, Sweden.

Hamm, LL; Nakhoul, N; Hering-Smith, KS (2015). Acid-base homeostasis. Clin J Am. Soc. Nephrol. 10(12): 2232-2242.

Heaton, FW 2003. Magnesium metabolism and its disorders. Clin Biochem Rev. 24(2):47-66.

Hertz-Piccitto, I (2000). The Evidence that lead increases the risk for spontaneous abortion, Am. J. Ind. Med. 38; 300-309.

Institute of Medicine (2001). Food and Nutrition Board. Dietary Reference Intakes for Vitamin A, Vitamin K, Arsenic, Boron, Chromium, Copper, Iodine, Iron, Manganese, Molybdenum, Nickel, Silicon, Vanadium, and Zinc Washington, DC: National Academy Press.

Jahnen-Dechent, W; Ketteler. M (2012). Magnesium basics. Clin Kidney J. 5(1): 13-14

Jaishankar, M; Tseten, T; Anbalagan, N; Mathew, B.B; Beeregowda, KN (2014). Toxicity, mechanism and health effects of some heavy metals. Interdiscip Toxicol. 7(2): 60-72.

Jarup, L (2003). Hazards of heavy metal contamination. Br Med Bull. 68(1):167-182. 
Jimoh, SO; Adeniyi, TE; Oladele, AT (2014). Production of wine from the fruit pulp of African star apple (Chrysophyllum albidum G.Don.). Nig. J Ecol. 13:34-46.

Kadiri, O; Kolawole, JT; Olawoye, B; Kadiri, AP (2016). Economic Studies on the Production of Fruit Juice from a Locally Sourced Fruit 'African Star Apple. TURJAF. 4(6): 438-445.

Keay, RWJ; Onochie, CFA; Stanfield, D (1964). Nigerian Trees. National Press Limited. 1. 219.

King, DE; Mainous, AG; Geesey, ME; Woolson, RF (2005). Dietary magnesium and C-reactive protein levels. J Am Col Nutr 24(3):166-171.

Koyejo, OA; Okonkwo, HO (2013). Storage methods and temperature variation on the preservation of Cola lepidota K. Schum fruit. Int J Appl. Res. Technol. 2(8): $79-86$.

Lenntech (2004). Water treatment and Air Purification, Lenntech, rotterdamseweg, Netherlands. Retrieved from www.excelwater.com/thp/filters/WatersPurification.htm. $1^{\text {st }}$ April 2019.

Liang, J; Liang, X; Cao, P; Wang, X; Gao, P; Ma, N; Li, N; Xu. H (2019). A preliminary investigation of naturally occurring Aluminum in grains, vegetables, and fruits from some areas of China and dietary intake assessment. J. Food Sci. 84(3): 701-710.

Maha, BO; Ahmed, YA (2015). Assessment of some heavy metals in fruit from local market in Khartoum state, Sudan Academy of Sciences (SAS) Atomic energy council. M. Sc thesis in Nuclear Sciences and Technology, Pp. 47.

McDowell, LR (2003). Minerals in animal and human nutrition 2nd ed. Amsterdam: Elsevier Science, p. 660 .

Mgbemena, NM; Ilechukwu, I; Okwhodolu. FU; Chukwurah, JO; Lucky, IB (2019). Chemical composition, proximate and phytochemical analysis of Irvingia gabonensis and Irvingia wombolu Peels, Seeds coat, Leaves and Seeds. Ovidius University Annals Chemistry 30 (1): 65 69.

Ming-Ho, Y (2005). Environmental toxicology: biological and health effects of pollutants, Chap. 12, pp 185-224, CRC Press LLC, 2nd Edition, Boca Raton, USA.
Mohammed, M; Bridgemohan, P; Mohammed, MS; Bridgemohan, RSH; Mohammed, Z (2017). Postharvest physiology and storage of Golden Apple (Spondias cytherea sonnerat or Spondias dulcis forst): A Review J Food Process Technol. 8: 707.

Muhammad, A; Sreebas, CB (2012). Assessment of heavy metals concentration in some selected medicinal plants collected from BCSIR, Chittagong cultivation area in Bangladesh. Hamdard Med. 55(3).

NAP (The National Academies Press). 1997. Dietary Reference Intakes for Calcium, Phosphorus, Magnesium, Vitamin D, and Fluoride. Washington, DC, USA: The National Academies Press

NBS (2011). Demographic Statistics Bulletin, 2010. National Bureau of Statistics, Abuja

NBS (2018). Demographic Statistics Bulletin, 2017. National Bureau of Statistics, Abuja

NIH (2020). National Institute of Health. U.S Dept. of Health and Human Services. Dietry Supplements Fact sheets (Iron), Available on https://ods.od.nih.gov/factsheets/IronHealthProfessional/\#en1 Accessed October, 2020.

Njenga, LW; Maina, DM; Kariuki, DN; Mwangi, FK (2007). Aluminium exposure from vegetables and fresh raw vegetable juices in Kenya. J Food, Agric. Environ. 5 (1): 8-11.

Nnaji, JC; Okereke, OB (2016). Proximate composition and physico-chemical properties of three Avocado (Persea americana) varieties in Umuahia, Nigeria. J. Appl. Chem. Sci. Inter. 5(4): 195-200.

Nwiisuator, DE; Oddo, EA; Emerhi, O; Sangha, P (2012). Mineral composition of Cola parchycarpa (K-schum) arils and seeds. AJFN. 2 (2):37- 41.

Ogbuagu, AS; Onyema, AO; Ekpunobi, UE; Onyema, CT (2015). Nutritional and heavy metal analysis on four local fruits in Awka, south Eastern Nigeria. Intl J Chem. Biomed Sci. 1(3):83-88.

Okhumode, HY (2018). Particle (soot) pollution in Port Harcourt Rivers State, Nigeria- Double Air Pollution Burden? Understanding and tackling potential Environmental public health impacts. Environ. 5(2); doi:10.3390/environments5010002. 
Olabanji, SO; Osinkolu, GA; Pelemo, DA; Obiajunwa, EI; Oladele, AT (2014). PIXE analysis of Thaumatococcus danielli in Osun State of Nigeria. Nucl Instrum. Methods Phys Res. B 318, $182-186$.

Oladele, AT; Fadare, OO (2015). Heavy metals and proximate composition of forest leafy vegetables in Oil producing area of Nigeria. EJESM. 8(4): $451-$ 463.

Oluwole, OB; Agboola, AA (2018). Dietary Iron Intake in Nigeria. NTNF. 1(4): 90-97.

Omoyajowo, KO; Kelechi, LN; Aderinola, BO (2017). Nutritional composition and heavy metal contents of selected fruits in Nigeria. JAEID. 111(1):123139.

Osuji, LC; and Ezebuiro, P.E. (2006). Hydrocarbon contamination of a typical mangrove floor in Niger Delta, Nigeria. IJEST. 3(3), 313-320.

Pandey, M; Abidi, AB; Singh, S; Singh, RR (2006). Nutritional Evaluation of leafy vegetable. Paratha J. Him. Ecol. 19 (2):155-156.

Pugalentha, M; Vadivel, V; Gurumoorthi, P; Janardhanam, K (2004). Comparative nutritional evaluation of little known legumes Tamaradus indica, Erythrina indica, Sesbania bispinosa. Tropical and Sub- tropical Agro-ecosystem (4): $107-123$.

Ruel, M; Harris, J; Cunningham, K (2013). Diet quality in developing countries, In: V.R. Preedy et al. (eds.), Diet Quality: An Evidence-Based Approach. Nutrition and Health 2. 239-261

Sabiha-Javied, H; Abudul, L; Najeebur, R; Muhammad, H; Tahir, S; Mudihra, N; Tasneem, B; Zabta, KS; In-jung, L (2009). Proximate and nutrient analysis of selected vegetables species: a case study of Kara region, Pakistan. Afr $J$ Biotechnol. 8 (12): 2725-2729.

Satarug, S; Garrett, SH; Sens, MA; Sens, DA (2010). Cadmium, Environmental exposure and health outcomes. Environ Health Perspect. 118(2), 182190.

Schwalfenberg, GK; Genuis, SJ (2017). The Importance of Magnesium in Clinical Healthcare. Scientifica. Volume 2017, Article ID 4179326, 14 pages

Swaminathan, R (2003). Magnesium metabolism and its disorders. Clin Biochem Rev. 24(2):47-66.

Tehoundjan, Z; Kenyue, J; Leaky, RRB (2002). Domestication of Dacryodes edulis: State of the forests. Trees and Livelihood 12:3-13.

Whistler, WA; Craig, RE (2006). Syzygium malaccense (Malay apple), Myrtaceae (myrtle family). Species profiles for Pacific Island agroforestry. Retrieved on August, 2019. From www.Traditionaltree.org Ver. 2.1.

WHO. 2008. Worldwide prevalence of anaemia19932005 WHO Global database on anaemia. Eds: B.de Benoist, E. McLean, I. Egli and M. Cogswell, WHO Press Geneva, Switzerland

World Health Organization (WHO) (1992). Environmental Health Criteria 134: Cadmium. Geneva, 280.

Zimmermann, MB; Hurrell, RF (2007). Nutritional iron deficiency, The Lancet 370(9586):51120, DOI:10.1016/S0140-6736(07)61235-5

Zukowska, J; Biziuk, M (2008). "Methodological evaluation of method for dietary heavy metal intake". J Food Sci. 73(2): R21-R29. 